This is the peer reviewed version of the following article: Rolfe, S. Models of SEND: the impact of political and economic influences on policy and provision. British Journal of Special Education,which has been published in final form at https://onlinelibrary.wiley.com/doi/ full/10.1111/1467-8578.12284. This article may be used for non-commercial purposes in accordance With Wiley Terms and Conditions for self-archiving.

\title{
Models of SEND: the impact of political and economic influences on policy and provision
}

Author: Dr Sue Rolfe 


\section{Introduction}

In this article, I hope to provide a clear and critical examination of how broader political issues and economic factors (such as periods of boom and bust) impact significantly on how well the current principles of inclusion and SEND are implemented through policy and provision. Two main aims will therefore be addressed. The first of these is to examine and critically evaluate the potential factors that may have an impact on the implementation of these principles. The second aim is to critically examine existing and new models of SEND and evaluate how they may be affected by different influences and thus reflect current political values.

\section{The concept of inclusion}

The concept of inclusion has been identified as a means to "remove barriers, improve outcomes and remove discrimination" (Lindsay, 2003:3), thus placing the impetus upon institutions to become more responsive to learners and their needs (Frederickson and Cline, 2010). This approach has changed the focus from attention upon a child's perceived deficits to the examination of the range of structures and approaches that schools use to provide equal access to and equity in learning for all pupils. Inclusion is therefore seen as important for the positive benefits such an approach could have in wider society, as it could challenge "narrow cultural parameters of normality" (Runswick-Cole, 2011:113), leading to greater acknowledgement and understanding of diversity and difference.

This concept has been supported by the United Nations through the creation and implementation of the Salamanca Statement on Principles, Policy and Practice in Special Needs Education and its associated Framework for Action (UNESCO, 1994). The Salamanca Statement is seen to identify an international commitment to inclusive education (Glazzard, 2013; Hardy and Woodcock, 2015) through the promotion of policies and policy change. The Statement and its Framework for Action was adopted by 92 governments and 25 international organisations following the World Conference on Special Needs Education, which took place in June 1994. The Statement reaffirmed the right to education for every individual and called upon governments to: 
adopt as a matter of law or policy the principle of inclusive education, enrolling

all children in regular schools, unless there are compelling reasons for doing

otherwise

(UNESCO, 1994: ix).

The terminology "all children" was expanded to identify disabled children, gifted, street and working children, those from nomadic and minority groups and those from other disadvantaged groups (UNESCO, 1994) as well as those children with disabilities or learning difficulties.

The focus on inclusion was to be achieved by assigning priority to policy and available budgets to improve education systems and through the development and establishment of mechanisms to plan, monitor and evaluate such provision (UNESCO, 1994). The supporting Framework for Action on Special Needs Education reaffirmed that inclusion and participation are "essential to human dignity and to the enjoyment and exercise of human rights" (UNESCO, 1994:11). Its purpose was to inform policy and provide guidance on implementing the statement principles at both national and school levels; the former should recognise the principle of equal opportunities through legislation and the latter through the consideration of curriculum, pedagogy, ethos, access and organisation.

However, Lindsay suggests that there is an implicit tension apparent in this Framework between what he describes as the "application of the proposed system for all children and a view that it may not be effective for all" (2003:4). He is referring to the continued focus on access to both mainstream and special education systems, which he suggests, impedes the development of inclusive policy. Lindsay also argues that the continued use of the policy caveats (that mainstream education must reflect the wishes of the parents and must not be incompatible with the education of other children), suggests that the policy of inclusion is still "insufficiently strong" and that "absolute commitment to total inclusion is necessary" (2003:5).

\section{Definition of SEND}

When examining policy in England, the most recent definition of SEND is outlined in the Special Educational Needs and Disability Code of Practice (DfE/DoH, 2015) and states that a child or young person has SEN if: 
they have a learning difficulty or disability which calls for special educational provision to be made for him or her

(DfE/DoH, 2015:15).

The definition is then expanded upon as the document examines what constitutes a learning difficulty or disability. This is explained as:

a significantly greater difficulty in learning than the majority of others of the same age, or

(if the child) has a disability which prevents or hinders him or her from making use of facilities of a kind generally provided for others of the same age

(DfE/DoH, 2015:16).

This current definition is seen to continue to reflect the longstanding emphasis in English policy on the need to support a range of identified children (Runswick-Cole and Hodge, 2009) and to identify specific learners who may experience difficulties at any time during their education (Terzi, 2005) and can therefore be seen to conflict with the concept of inclusion. Although the term SEND has been positively received by many for initiating changes in attitudes and language use and enabling greater numbers of children to access mainstream schooling (Runswick-Cole and Hodge, 2009; Attwood, 2013), other researchers such as Norwich consider that:

the way the concept of SEN has been used in theory and practice has been contentious from its inception

(2014:417)

as issues have been raised regarding the lack of explanation of the term and the view that its use continues to label children.

\section{Aim 1: Factors affecting the current inclusion agenda}

Economic and financial instability

At both national and global levels, governments often have to manage periods of "socio-economic crisis" (Carpentier, 2009:194), which may occur either due to a crisis in the banking system, or the crises which Avis (2011:423) refers to as those "that are inherent to the capitalist system...the tendency towards boom and bust". Governments must also consider a growing demographic pressure upon financial 
reserves. This includes an aging population; a smaller proportion of the population are working and contributing to the state through taxation. The discrepancy between taxation income and pension funding may then impact upon the budgets available for welfare provision.

The most recent financial crisis occurred in 2008. Gamble suggests that the reaction of the market "was so extreme that the financial system appeared to be on the point of collapse", which could cause major disruption "to the international economy, to public order and to political stability" (2010:703). The subsequent global recession forced governments to use large amounts of their financial reserves to bail out the banks. Richardson (2010:495) suggests that governments implement two stages of response to such a crisis, and these are "a period of stimulus followed by a move towards austerity", as there is then an emphasis on reducing public spending. Gamble extends this idea and suggests that a large increase in deficits initially took place in 2009, due partly to a "bank rescue package" (2010:704). He continues by stating that national governments are now focussing on deficit reduction plans, which will inevitably affect a range of frontline services, including education. The wider implications for education, suggest therefore, that continuing reductions in funding, (to enable central government to meet its austerity targets), may impact significantly upon a school's ability and flexibility to support pupils, especially those with SEND, as funding will have to be prioritised, and planning developed, to ensure that remaining budgets are utilised in the most efficient way. Funding cuts may also impact upon existing international commitments to inclusive education.

The United Nations Convention on the Rights of Persons with Disabilities [UNCRPD], (United Nations, 2006) was the first convention protecting the human rights of individuals with disabilities (Harpur, 2012; Hyatt and Hornby, 2017). This Convention came into force in 2008 , recognising the right to equality and nondiscrimination through the right to access schools and education programmes, public transport and buildings (Harpur, 2012). Article 24 of this convention reinforced the right both to education and for there to be an inclusive education system (at all levels of schooling) involving the implementation and use of appropriate resources to support individuals (Byrne, 2013). Hyatt and Hornby (2017: 290) identify that UN General Comment number 4 (2016) called for countries "to begin to take measures, 
within the bounds of their available resources, to achieve the progressive implementation of inclusive education". At this time of current financial constraints, it is not inconceivable to suggest that the concept of inclusive education and the subsequent allocation of a significant budget to support such a system, are not immediate priorities for national government agendas.

\section{The standards agenda}

Although the current educational focus is on promoting inclusion, there is a dichotomy apparent between this concept and the prevailing political agenda to drive up standards. Ainscow et al., define such an agenda as an "approach to educational reforms which seeks to 'drive up' standards of attainment, including workforce skill levels and ultimately national competitiveness in a globalised economy" (2006:296). They comment that this approach is 'intimately linked' to other policy areas, including the 'marketisation of education... and a regime of target setting and inspection...to force up standards' (ibid: 296) and this notion is supported by Norwich (2014). The increased influence of the state is also apparent through the centralised introduction of a National Curriculum and its assessment procedures, which result in detailed target setting and the provision of data.

There has been concern that the current policy agenda to raise standards may well be incompatible with inclusion, if "only measures of attainment are used to define achievement" (Glazzard, 2013: 182). Some pupils with additional needs may never be fully able to achieve these expected levels; instead, they are identified and labelled by their inabilities, rather than recognising any personal achievements which may not be measurable against norm related standards. Rix et al acknowledge that the standards policy discourse creates "a tension between a focus upon outputs and support for the vulnerable" (2013: 376). The desire to gain international recognition for educational and therefore economic achievement drives policy that could effectively reduce access and ultimately exclude a proportion of the population.

\section{The use of attainment data}

The publication of attainment data occurs in many countries, including England. Power and Frandji (2010:386) suggest that this process has been seen as "an integral part of stimulating market forces in education" as knowledge has become an “important aspect for national economic competitiveness" (Stangvik, 2014: 92). 
Lauder et al (2006) acknowledge the importance of acquiring knowledge and skills as these add to an individual's credentials when competing in the economic workplace. They also identify, however, that individuals without these skills are excluded from access to opportunities that are readily available to others. Children with SEND are often seen to be an "impediment" to a school achieving positive academic outcomes (Mintz and Wyse, 2015:1161), as they negatively affect standards of attainment. For pupils with SEND, the influence of the market on the education system may negatively affect their ability to access equitable provision.

The constant attention placed upon standards and targets, along with the imposition of a national curriculum that emphasises academic subjects and assessment, puts at risk vulnerable pupils and can lead to their ultimate exclusion, either as a result of "increased drop out and poor retention rates" (Smith and Douglas, 2014: 452). This can be due to the need to meet unattainable targets, or because schools will be more reluctant to admit pupils who will not be able to make the required progress. According to Leo and Barton (2006), the focus on standards has led to the purpose of education becoming aligned with an emphasis on outcomes, performativity and the requirement to be competitive. Lloyd (2008:226) expands on this idea by identifying that there is a particular impetus to develop a "common set of basic skills which are geared towards the labour market", thus narrowing the range of achievements education can potentially provide for pupils and creating possible difficulties for those who are unable to achieve the required standards.

\section{Aim 2: Models of SEND}

There are three established models of SEND. Garner identifies these models as "sets of concepts, ideas and practices" (2009:26). In this section, these models and two new ones will be critically examined regarding how they may be expressed in policy content and also reflect the political values that are apparent at that time.

\section{The medical model}

This approach has been described as "the traditional ideology through which Western society has conceptualised SEN and disability" (Hodkinson, 2016:20). The model adopts the viewpoint that the problem or difficulty lies within the child and his or her impairment, and therefore constructs this difference as problematic (Glazzard, 
2011). Harpur suggests that as a particular problem is identified, the model looks for a 'cure' (2012:2).

The success of intervention in this model relies upon accurate assessment of the individual's impairment. The identification and categorisation of need, and the subsequent provision of appropriate support, requires the judgement of relevant professionals (Hodkinson, 2016). However, Evans (2007:47) suggests that this system is "both rigid and arbitrary" as the emphasis upon an individual's deficits fails to consider any strengths the person possesses, or the effects of the environments they exist in, which may then either reduce or compound the difficulties they face. As a result of such assessments, Hodkinson (2016:23) suggests that "children who do not conform to learning environments are labelled and often removed from mainstream classrooms".

Although the limitations of the medical model have been criticised, it has since been suggested, that due to an "explosion" of diagnoses of ADHD and Dyslexia, it "has experienced something of a renaissance" (Hodkinson, 2016:26). This suggestion could link to Riddell's argument (2007) that some parents are now proactively exercising their market rights in order to ensure that their children receive appropriate support and have access to resources. Although achieving such support may involve an assessment that could lead to a definition of special educational needs, parents see the label as necessary to ensure this support. Tomlinson (2012) also argues that middle class parents, promised more choice by successive governments, are now making such demands.

The potential use of this model in policy content can lead to a deficit-focused approach to meeting the needs of individuals, reliant on medical solutions. This emphasis can be identified in the SEND Code of Practice (DfE/DoH, 2015) as it focuses on four areas of need and the requirement to record a child's primary SEND following the completion of identification, assessment and diagnosis. The importance placed upon remediation and intervention also reflects the government's priority of addressing national standards in order to compete with other countries in international league tables. 


\section{The social model}

In contrast to the medical model, the focus of the social model is to remove the difficulty or problem from the individual, considering it instead the "collective responsibility of society" (Runswick-Cole and Hodge, 2009:109). Liasidou (2012:115) further suggests that the aim of the model is to emphasise the interrelationship between the "private and the public", (individual and society) and identify factors that may affect the nature of this relationship that are to the detriment of the individual.

The model moves away from viewing impairment as the result of the difficulties that arise from deficits. It uses the alternative term of 'disability' and argues that the difficulties that arise for individuals are a result of different aspects of society (Liasidou, 2012). Oliver (2013) expands upon this idea and suggests that the model identifies that individuals are disabled not by their impairments, but because of the barriers imposed by the society in which they live. As a result, impairment becomes disabling (Harpur, 2012). Society therefore, is required to identify and remove barriers, whether environmental, cultural or structural, to enable individuals to achieve full participation in the community. Disability is viewed only as a social construction that exists because of those inhibiting factors (Barnes and Sheldon, 2007; Liasidou, 2012).

Reliance upon medical assessments is also questioned and supporters of this model suggest that individuals are negatively labelled and disempowered due to the emphasis on diagnoses and assessments. The use of labels can affect the attitudes held by communities towards individuals, potentially leading to discrimination and prejudice due to lack of knowledge and understanding of the condition or disability. Armstrong expands upon this argument by suggesting that impairments are "reflective of the diversity of the human condition" and that they only become disabilities when individuals are disadvantaged because of their differences (2005:142).

The statutory Inclusion Statement (section 4 in the English National Curriculum document) (DfE, 2013:8), identifies that teachers should "set suitable challenges" and 'respond to pupils' needs and overcome potential barriers for individuals and groups of children". These principles emphasise the importance of both external factors (as potentially impacting upon the learning of pupils with SEND) and 
teachers' expertise and ability in planning and teaching and can be associated with the principles of the social model. This focus is in direct contrast to the importance of the medical model demonstrated in the SEND Code of Practice (DfE/DoH, 2015) and the emphasis upon factors that are internal to the child (Hodkinson, 2016). The importance placed on inclusive practice also conflicts with the government's previous argument (as stated in the Conservative 2010 election manifesto), that there has been a bias towards inclusion and the belief that SEND has previously been over identified.

The medical and social models both have theoretical weaknesses as each model provides a separate and diametrically opposite locus for the causes of disability and/or impairment. The biopsychosocial model addresses these difficulties.

\section{The biopsychosocial model}

This model of health and illness was first proposed by Engel in 1977. He argued that psychological and social factors influenced biological functioning, stating that:

No system exists in isolation. Whether a cell or a person, every system is influenced by the configuration of the systems of which each is a part, that is, by its environment (1981:106).

He suggested that the "crippling flaw" of the medical model was that it did not include "the patient and his attributes as a person, a human being" (1981:103). In 2001, the World Health Organisation (WHO) published the International Classification of Functioning, Disability and Health (ICF) and Hodkinson (2016) identifies that Engel's model provides the basis for this framework. Glazzard (2019:307) states that the ICF recognises "the complex interrelationships between biological and contextual factors that influence how disability is experienced by the individual".

The biopsychosocial model is seen to be an interactive process between biological, psychological and social factors (Suls and Rothman, 2004; Molina, 1983). Norwich (2002:495) identifies the need for such a model, stating that even if one aspect is dominant, others may still have "some contributory interactive impact". This idea is continued by Hodkinson (2016:179) who identifies that this model recognises the "complexity of SEN", rather than continuing the individualistic approaches of the previous models. The benefits of viewing these three factors holistically is reiterated by Nassir Ghaemi (2009). 
Hodkinson (2016:179) suggests that this model "embraces" both the medical and social models, and removes any emphasis that is solely based on individual or societal factors. Any external barriers that may affect children's educational progress should now be examined, thus eliminating the use of labelling individuals because of their "individual pathology" (Runswick-Cole, 2011:114). Consideration should also be given to the impact of social, cultural or environmental factors upon the "phenomenon of disability" (Reindal, 2008:141). Focus can also be given to the 'within-child' factors that exist because of the needs of the individual and the issue of their interaction with the environment (Lindsay (2003). However, Nassir Ghaemi (2009) also cautions that the model does not provide guidance on how to prioritise these factors in order to support the individual as effectively as possible.

When considering the use of this model in policy in England, it is positively reflected in the content and purpose of the National Curriculum Inclusion Statement (as it advocates examining all of the aspects that may impact a child's learning) and also the UNCRPD (UN, 2006). However, as previously stated, implementation may be affected by funding and budgetary restrictions.

This article will now introduce two new models proposed by the author: the state influenced market model and the financial crisis model.

\section{Model 1: The state-influenced market model}

This model argues that there is a strong focus in much government thinking that a nation's education system is a principal means of raising the knowledge and skills base of individuals in order to enhance economic efficiency (Le Grand et al., 2008). However, as suggested by Le Grand (2003) and Bradbury et.al, (2013), there have been significant changes in policy-makers' perceptions, which have resulted in "a policy drive to replace state-based delivery systems by market-based ones... to serve the (newly discovered) consumers of public services" (Le Grand, 2003:23). This has resulted in reforms designed to increase consumer choice and to ensure that providers become more responsive to their users (Le Grand et al., 2008). These changes have been summarised in this article as the 'state-influenced market model'. 
As a result of this model, parents become "the driving force behind change in the education system", with the powers of schools and local authorities reduced as they "become subordinate to the needs of the parents" (Wright, 2012:284). Within this model, parents and children are the 'consumers' of education. Teachers are the 'producers', who, Ranson suggests, are seen as having "pursued their own ideas and interests" at the expense of the consumers (1990:8). This viewpoint has provided evidence and support for greater rights and choice for parents within the education system.

For some 'consumers', who have children with SEND, this state-influenced market model has provided them with greater opportunity of choice regarding support for their children's needs. The Special Educational Needs and Disability (SEND) Code of Practice (DfE/DoH, 2015) states that if a child has been issued with an Education, Health and Care Plan, parents have the right, if they so choose, to assume responsibility of the individual budget available to support their child. Parents would be able to use their knowledge and understanding of their child's needs to commission the services of a range of providers to support their child both in and out of the school setting.

Norwich counters this idea however, by suggesting that there is "no longer term vision" of how this provision "is interconnected with or dependent on the wider education service" (2014:415). This change has been introduced alongside greater opportunities for community and voluntary services to act as providers. Such a change may then be seen as having the potential to reduce, as well as increase, the types of provision available, as this new market place may also negatively impact upon the resources and support schools and/or local authorities are able to provide as their budgets would be reduced as funding is allocated to other providers.

Although greater parental choice is identified in positive terms, the possibility of exercising this choice may not be able to be achieved equally for all parents, particularly those whose children have SEND. Le Grand (2003) refers to the notion of "cream skimming", where selection of pupils of high ability may take place at an oversubscribed school, in order to improve exam and league table performance. This can lead to "polarisation or segregation in terms of ability with able pupils being 
increasingly concentrated in high-performing schools and less able pupils in lowperforming ones" (2003:110).

This may result in particular consequences for communities and their diversity, as the right to choose can lead to increased segregation with regard to both social class and special educational needs. As attainment can be linked to a child's socioeconomic background, other schools may close or become poorly resourced 'sink' schools where the pupil population is comprised of children who are academically low achieving, have SEND or are economically disadvantaged (Gorard et al., 2003). Walford (2008) expands upon this issue by suggesting that this disadvantage can worsen over time, as a school then becomes less able to respond to or improve its situation. Any available budgets to fund support may also be impacted upon due to funding cuts that are considered a priority because of the prevailing economic situation.

\section{Model 2: The financial crisis model}

The management of crises has been dealt with in a number of ways. Before 1945, Carpentier (2009:194) identifies that governments increased levels of public spending, particularly in education, to "revive productivity levels by developing the workforce in conjunction with new innovations". He also suggests that after 1945, a further change took place as "educational development became not only a way out of the crisis, but a driver of economic growth" (ibid); funding for education therefore became imperative in enabling post-war economic growth and development.

A change in policy direction took place however, during the economic crisis of the 1970 s as, for the first time the economic downturn was also matched by a reduction in the public funding provided for education. This type of reduction was also a central concern during the 1980s and 1990s, as governments planned to reduce deficits. According to Levin (2001:71), many reforms "were at least partly about efforts to control costs or to improve productivity", in order to increase a country's ability to successfully engage in a global economy.

A number of researchers identified that at the time of the 2008 crisis, the major UK political parties shared a "single position" (Jones, 2010:793). This was that the country's problems were debt related, requiring a "massive shock therapy, in the 
form of cuts in public spending" in order to solve them (ibid; Avis, 2011; Gamble, 2010). Reforms to public expenditure can be associated with the current neo-liberal discourse, as the approaches associated with this ideology emphasise the use of "management... competition, cost cutting and efficiency" (Bates, 2012:90) to achieve economic and financial success.

Taylor-Gooby (2012:62) has suggested that the objective of the Coalition government (elected in 2010), was the introduction of "permanently lower spending, lower debt and market-led growth", to be achieved through a "shift of responsibility in many areas, from state to private providers, citizens or the community", thus reemphasising neo-liberal approaches. Avis reinforces this idea and identifies that there is a political agenda apparent to "re-order the relationship between the state and the welfare/public sector" (2011:421) and that the Conservative government elected in 2015 has continued this agenda.

Gamble has argued that the politics underpinning spending cuts "lays bare the nature of the state and its priorities" (2010:705), as choices have to be made "about which departments and social groups should carry the heaviest burden". This impact is often felt most acutely by those who are already facing difficulties, whether this is due to cuts to welfare budgets or lack of employment prospects due to the economic downturn (Richardson, 2010). Taylor-Gooby (2012) has proposed that such changes are part of a systematic reform, which moves beyond immediate cost cutting measures and seeks to modify the long-term context in which provision and policy is enacted. The same author claims that it is likely that such changes will continue to "damage living standards for some of the poorest groups. The likely outcome is an increase in poverty and inequality" (ibid: 78), thus continuing to create difficulties for specific groups and individuals.

Policy decisions on SEND may be made primarily because of the demands that arise from this approach. A government may not wish to acknowledge the power of this influence, however, and may use any of the other models as justification for any selected policy direction. 


\section{Models of SEND and wider influences}

As previously identified, the second aim of this article is to examine existing and new models of SEND and to evaluate how they may be influenced by different drivers and thus reflect current political values.

The medical model portrays the individual and his/her impairment as the problem, which requires intervention in order to 'fix' the issue. As a result, attention is seldom given to the wider context in which the individual lives and how modifications to this context may enable greater equity. This idea is examined however, in the social model as it emphasises that a range of societal barriers can impede the lives of people with impairments, causing them to feel disempowered and discriminated against until these barriers are removed through the external intervention of the state. The biopsychosocial model also promotes the implementation of individual legal rights to equity, and the role of governments in ensuring these. The stateinfluenced market model concentrates on raising economic efficiency as well as providing choice for its consumers. The financial crisis model and the priorities that are established due to the necessity to manage national budgets, may however, impact upon this approach. This may include reductions in funding for projects that aim to increase access to services for people with disabilities, thus continuing the potential of their exclusion from equity of choice and participation.

The principles of these models have previously been identified in current international and national policy. However, there are also broader external influences that impact significantly on how such policy is implemented in practice and the subsequent provision of support and resources. The table presented below (Table 1) identifies these influences as: political, economic and educational and identifies how they may impact on the use of the models of SEND in policy content and direction.

\section{Summary}

The models examined in this article adhere to vastly different perspectives regarding the concepts of inclusion and SEND. Hodkinson (2016:21) suggests that these conceptualisations "are embedded within the consciousness of society and reveal themselves through such things as...policy". The introduction of the new models in particular links closely to this statement and also to Lauchlan and Greig's (2015) 
suggestion that the values embedded in legislation reflect the attitudes that exist at the time of implementation.

Many positive policy developments can be associated with the social and biopsychosocial models, as advances have been made with regard to educational and social equity. However, there are also apparent limitations such as the use of neo-liberal approaches, budget reductions and restrictions and the standards agenda that negatively affect such progress. With the current emphasis on developing a skilled workforce and making global comparisons of education and economic efficiency, the identified political, economic and educational influences may create long-term difficulties for individuals with SEND. 


\section{$\underline{\text { References }}$}

Ainscow, M., Booth, T. and Dyson, A. (2006) Inclusion and the standards agenda: negotiating policy pressures in England, International Journal of Inclusive Education, 10 (4-5), pp.295-308.

Armstrong, D. (2005) Reinventing 'inclusion': New Labour and the cultural politics of special education, Oxford Review of Education, 31(1), pp.135-151.

Attwood, L. (2013) The real implications of 'benevolent' SEN reform, Support for Learning, 28(4), pp. 181-187.

Avis, J. (2011) More of the same? New Labour, the Coalition and Education: markets, localism and social justice. Educational Review, 63(4), pp.421-438.

Barnes, C. and Sheldon, A. (2007) 'Emancipatory' disability research and special educational needs. In L. Florian (Ed.) The Sage Handbook of Special Education, London: Sage, pp.233-245.

Bates, A. (2012) Transformation, trust and the 'importance of teaching': continuities and discontinuities in the Coalition government's discourse of education reform. London Review of education, 10(1), pp.89-100.

Bradbury, A., McGimpsey, I. and Santori, D. (2013) Revising rationality: the use of 'Nudge' approaches in neo-liberal education policy. Journal of Education Policy, 28(2), pp.247-267.

Byrne, B. (2013) Hidden contradictions and conditionality: conceptualisations of inclusive education in international human rights law. Disability and Society, 28(2), pp.232-244.

Carpentier, V. (2009) The credit crunch and education: an historical perspective from the Kondratiev Cycle. London Review of Education, 7(2), pp.193-196.

DfE [Department for Education] (2013) National Curriculum in England. DfE online publication:

https://assets.publishing.service.gov.uk/government/uploads/system/uploads/attach ment data/file/425601/PRIMARY national curriculum.pdf

Downloaded: $8^{\text {th }}$ April 2019.

DfE/DoH [Department for Education/Department of Health] (2015) The Special

Educational Needs and Disability Code of Practice: 0 to 25 years.

DfE online publication:

https://assets.publishing.service.gov.uk/government/uploads/system/uploads/attach ment data/file/398815/SEND Code of Practice January 2015.pdf

Downloaded: 17th June 2019

Engel, G. L. (1981) The clinical application of the Biopsychosocial model. The Journal of Medicine and Philosophy, Vol 6, pp. 101-123. 
Evans, J. (2007) Forms of provision and models of service delivery. In L. Florian (Ed.) The Sage Handbook of Special Education, London: Sage, pp.46-54.

Frederickson, N. and Cline, T. (2010) Special Educational Needs, Inclusion and Diversity. Berkshire: Open University Press.

Gamble, A. (2010) After the Crash. Journal of Education Policy, 25(6), pp.703-708.

Garner, P. (2009) Special Educational Needs-The key concepts. Oxon: Routledge.

Glazzard, J. (2011) Perceptions of the barriers to effective inclusion in one primary school: voices of teachers and teaching assistants, Support for Learning, 26(2), pp. 56-63.

Glazzard, J. (2013) A critical interrogation of the contemporary discourses associated with inclusive education in England, Journal of Research in Special Educational Needs, 13(3), pp. 182-188.

Glazzard, J. (2019) "What can teachers do to raise outcomes for children with special educational needs and disabilities?" In C. Carden (Ed.) Primary Teaching, London: Sage, Learning Matters, pp.299-318.

Gorard, S., Taylor, C. and Fitz, J. (2003) Schools, markets and choice policies. London: Routledge Falmer.

Hardy, I. and Woodcock, S. (2015) Inclusive education policies: discourses of difference, diversity and deficit, International Journal of Inclusive Education, 19(2), pp.141-164.

Harpur, P. (2012) Embracing the new disability rights paradigm: the importance of the Convention on the Rights of Persons with Disabilities, Disability and Society, 27(1), pp. 1-14.

Hodkinson, A. (2016) Key Issues in Special Educational Needs and Inclusion. (2 $2^{\text {nd }}$ edition). London: Sage.

Hyatt, C. and Hornby, G. (2017) Will UN Article 24 lead to the demise of special education or to its re-affirmation? Support for Learning, 32(3), pp.288-304.

Jones, K. (2010) Crisis, what crisis? Journal of Education Policy, 25(6), pp.793-798.

Lauder, H., Brown, P., Dillabough, J. and Halsey A.H. (Eds.) (2006) Education, Globalisation and Social Change. Oxford: Oxford University Press.

Le Grand, J. (2003) Motivation, Agency and Public Policy. Oxford: OUP.

Le Grand, J., Propper, C. and Smith, S. (2008) The Economics of Social Problems. ( $4^{\text {th }}$ edition). Basingstoke: Palgrave MacMillan.

Leo, E. and Barton, L. (2006) Inclusion, diversity and leadership: perspectives, possibilities and contradictions, Educational Administration and Leadership, 34(2), pp.167-180. 
Levin, B. (2001) Reforming Education: from origins to outcomes. London: Routledge Falmer.

Liasidou, A. (2012) Education, politics and policymaking, London: Continuum.

Lindsay, G. (2003) Inclusive Education: A critical perspective, British Journal of Special Education, 30(1), pp.3-12.

Lloyd, C. (2008) Removing barriers to achievement: A strategy for inclusion or exclusion? International Journal of Inclusive Education, 12(2), pp.221-236.

Mintz, J. and Wyse, D. (2015) Inclusive pedagogy and knowledge in special education: addressing the tension, International Journal of Inclusive Education, 19 (11) pp.1161-1171.

Molina, J. (1983) Understanding the biopsychosocial model. International Journal of Psychiatry in Medicine, 13(1), pp.29-36.

Nassir Ghaemi, S. (2009) The rise and fall of the biopsychosocial model. The British Journal of Psychiatry, Vol. 195, pp.3-4.

Norwich, B. (2002) Education, inclusion and individual differences: recognising and resolving dilemmas. British Journal of Education Studies, 50(4), pp.482-502.

Norwich, B. (2014) Changing policy and legislation and its effects on inclusive and special education: a perspective from England. British Journal of Special Education, 41(4), pp.403-425.

Oliver, M. (2013) The social model of disability: thirty years on. Disability and Society, 28(7), pp.1024-1026.

Power, S. and Frandji, D. ((2010) Education markets, the new politics of recognition and the increasing fatalism towards inequality, Journal of Education Policy, 25(3), pp.385-396.

Ranson, S. (1990) From 1944 to 1988: Education, citizenship and democracy. In M. Flude and M. Hammer (Eds.) The Education Reform Act 1988. Basingstoke: The Falmer Press, pp.1-19.

Reindal, S.M. (2008) A social relational model of disability: a theoretical framework for special needs education? European Journal of Special Needs Education, 23(2), pp.135-146.

Richardson, D. (2010) Child and Family Policies in a time of economic crisis. Children and Society, 24, pp.495-508.

Riddell, S. (2007) A sociology of special education. In L. Florian (Ed.) The Sage Handbook of Special Education, London: Sage, pp.34-45.

Rix, J., Sheehy, K., Fletcher-Campbell, F., Crisp, M. and Harper, A. (2013) Exploring provision for children identified with special educational needs: an international review of policy and practice, European Journal of Special Needs Education, 28(4), pp. 375-391. 
Runswick-Cole, K. and Hodge, N. (2009) Needs or rights? A challenge to the discourse of special education, British Journal of Special Education, 36(4), pp.198203.

Runswick-Cole, K. (2011) Time to end the bias towards inclusive education? British Journal of Special Education, 38(3), pp.112-119.

Stangvik, G. (2014) Progressive education in the neoliberal context, European Journal of Special Needs Education, 29(1), pp.91-104.

Suls, J. and Rothman, A. (2004) Evolution of the biopsychosocial model: prospects and challenges for health psychology. Health Psychology, 23(2), pp.119-125.

Taylor-Gooby, P. (2012) Root and branch restructuring to achieve major cuts: the social policy programme of the 2010 UK Coalition government. Social Policy and Administration, 46(1), pp.61-82.

Terzi, L. (2005) Beyond the dilemma of difference: The capability approach to disability and special educational needs, Journal of Philosophy of Education, 19(3), pp.443-459.

Tomlinson, S. (2012) The irresistible rise of the SEN industry. Oxford Review of Education, 38(3), pp.267-286.

United Nations (2006) Convention on the Rights of Persons with Disabilities. United Nations.

United Nations Committee on the Rights of Persons with Disabilities (CRPD), General comment No. 4 (2016), Article 24: Right to inclusive education, 2 September 2016, CRPD/C/GC/4, available at:

https://www.refworld.org/docid/57c977e34.html [accessed 8 April 2019]

UNESCO [United Nations Educational Scientific and Cultural Organisation] (1994) The Salamanca Statement and Framework for Action on Special Needs Education. Paris: UNESCO.

Walford, G. (2008) School choice in England: globalisation, policy borrowing or policy competition? In M. Forsey, S. Davies and G. Walford (Eds.) The globalisation of school choice? Oxford: Symposium Books, pp.95-109.

World Health Organisation (2001) Towards a Common Language for Functioning, Disability and Health. Geneva: The International Classification of Functioning, Disability and Health. World Health Organisation.

Wright, A. (2012) Fantasies of empowerment: mapping neo-liberal discourse in the coalition government's school policy. Journal of Education Policy, 27(3), pp. 279294. 


\section{Table 1: Wider influences impacting on models of SEND}

\begin{tabular}{|c|c|c|c|c|c|}
\hline & Medical model & Social model & $\begin{array}{c}\text { Biopsychosocial } \\
\text { model }\end{array}$ & $\begin{array}{c}\text { State influenced } \\
\text { market model }\end{array}$ & $\begin{array}{c}\text { Financial crisis } \\
\text { model }\end{array}$ \\
\hline $\begin{array}{l}\text { Economic } \\
\text { influences }\end{array}$ & $\begin{array}{l}\text { Reduced budgets } \\
\text { and funding to } \\
\text { central government } \\
\text { services due to the } \\
\text { drive to meet } \\
\text { austerity targets. }\end{array}$ & $\begin{array}{l}\text { Reduced budgets and } \\
\text { funding to central } \\
\text { government services } \\
\text { due to the drive to } \\
\text { meet austerity } \\
\text { targets. }\end{array}$ & $\begin{array}{l}\text { Reduced budgets } \\
\text { and funding to } \\
\text { central government } \\
\text { services due to the } \\
\text { drive to meet } \\
\text { austerity targets. }\end{array}$ & $\begin{array}{l}\text { Reduced budgets and } \\
\text { funding to central } \\
\text { government services } \\
\text { due to the drive to meet } \\
\text { austerity targets. }\end{array}$ & $\begin{array}{l}\text { Impact of the global } \\
\text { financial crisis of } \\
2008 \text { on national } \\
\text { and international } \\
\text { monetary systems. }\end{array}$ \\
\hline $\begin{array}{l}\text { Educational } \\
\text { influences }\end{array}$ & $\begin{array}{l}\text { 1. Disapplication of } \\
\text { pupils from SATs } \\
\text { based on SENDs. } \\
\text { 2. Focus on } \\
\text { remediating } \\
\text { individual needs } \\
\text { instead of } \\
\text { addressing the } \\
\text { system. } \\
\text { 3. No/little flexibility } \\
\text { in approaches- } \\
\text { "disabling". } \\
\text { 4. Lack of focus on } \\
\text { individual strengths. }\end{array}$ & $\begin{array}{l}\text { 1. Inclusion } \\
\text { 2. Policy and } \\
\text { legislation } \\
\text { (international and } \\
\text { national)-right to an } \\
\text { education that meets } \\
\text { individual needs. } \\
\text { 3. Flexibility in } \\
\text { approaches-"abling". } \\
\text { 4. Remove barriers } \\
\text { e.g. curriculum, } \\
\text { organisation, } \\
\text { attitudinal, } \\
\text { environmental. }\end{array}$ & $\begin{array}{l}\text { 1. Inclusion } \\
\text { 2. Policy and } \\
\text { legislation } \\
\text { (international and } \\
\text { national)-right to an } \\
\text { education that } \\
\text { meets individual } \\
\text { needs. } \\
\text { 3. Flexibility in } \\
\text { approaches-“abling" } \\
\text { 4. Remove barriers } \\
\text { e.g. curriculum, } \\
\text { organisation, } \\
\text { attitudinal, } \\
\text { environmental. }\end{array}$ & $\begin{array}{l}\text { 1. National Curriculum } \\
\text { and assessment } \\
\text { procedures-all children } \\
\text { expected to make } \\
\text { required levels of } \\
\text { progress. } \\
\text { 2. No focus on broader } \\
\text { educational goals life } \\
\text { skills, social skills etc. } \\
\text { 3. To increase the UK's } \\
\text { standing in international } \\
\text { league tables of } \\
\text { educational success. } \\
\text { 4. Emphasis on } \\
\text { improving the academic } \\
\text { skills and training of all } \\
\text { children (including } \\
\text { those with SEND) to } \\
\text { develop a highly trained } \\
\text { workforce. }\end{array}$ & $\begin{array}{l}\text { 1. Reduction in } \\
\text { school's budgets } \\
\text { and subsequent } \\
\text { impact in all areas, } \\
\text { including funding of } \\
\text { support for SEND. } \\
\text { 2. Negative impact } \\
\text { on levels of staffing } \\
\text { and resource } \\
\text { provision. }\end{array}$ \\
\hline
\end{tabular}

